\title{
Accounting Policies and Comparability of Companies' Financial Reports in Nigeria
}

\author{
Dr. Augustine O. Okolie ${ }^{1}$; Omoregie, A. E. Nosa ${ }^{2}$ \\ ${ }^{I}$ Department of Accounting, Faculty of Management Sciences, Ambrose Alli University,Ekpoma, Nigeria, \\ ${ }^{2}$ Department of Accounting, Faculty of Management Sciences, Ambrose Alli University, Ekpoma, Nigeria,
}

\begin{abstract}
This study examines uniformity and comparability of accounting policies of quoted companies in Nigeria. The design employed in data collection is a cross-sectional survey of the accounting policies of 12 companies listed on the Nigerian Stock Exchange (NSE). The study tested four critical areas of financial reports of companies including quality, presentation, disclosure and content of financial statements of the sampled companies. The results achieved by applying the chi-square statistic using U.M.P. invariant test, suggests that accounting policies are uniform in the form, types of number presented, the layout or format and management of accounting policies. However, their accounting practices are not uniform in the areas of quality, disclosure and content of financial statements and hence, their overall accounting practices. It is submitted that similar nomenclatures should be adopted in the accounting policies and financial statements preparations of all listed companies in NSE in order to increase uniformity, understandability and comparability of financial reports of companies in Nigeria.
\end{abstract}

Jel: JEL: G11, M41, M42, P34

Keywords: Accounting, Accounting Policies, Financial Reports, Financial Disclosures

\section{Introduction}

Stakeholders look into the existing financial guidelines in listed companies and the efficiency of audit process with a view to making them more effective [1]. This presidential declaration is to ensure accountability and responsible governance in the Nigerian Stock Exchange. In order to instill transparency and accountability in listed companies on the Nigerian Stock Exchange, the extent of compliance with relevant accounting standards, legal requirements and a test of uniformity and comparability of the accounting practices and the resulting financial reports is desirable.

According to Pandey [2], finance as it is known, is the bedrock of which the existence of any organization lies. Stakeholders in an organization are expected to be interested in the financial position of the organization they have a stake in. it is, therefore surprising that stakeholders in non-profit making organization like Tony Foundations are not listed in Nigerian Stock market, not to talk of the stakeholder's poor concern about the accounting practices of the organizations [3] [4].

Following from the above, the rationale for choice of this subject matter is the lack of understanding of the nature of accounting policies in listed companies in Nigeria coupled with the absence of an International Accounting Standard (IAS) for listed companies, more so, the financial statements of these companies, thereby negating transparency and accountability which are panaceas for economic growth in a democratic governance.

The main objective of this paper is to throw more light on accounting policies practice in listed companies in Nigeria in terms of the presentations, disclosure and content of their financial reports. In achieving this, the remainder of the paper proceeds as follows: In section two, a brief content of the Accounting policies was done. In section three, the data collection procedures as well as the measures used to capture accounting policies was described. Section four reports the primary result while section five conclude and considers some recommendations.

\section{Literature Review}

Various authors have attempted to study the problems of accounting policy from the process of accounting policy decision making. Herdsman [5] has defined accounting policy as one that is very important to the portrayal of the company's financial conditions and results and requires judgments. Typically, a critical accounting policy involves a new complex of accounting standards (often based on new business practices) that is particularly sensitive to estimates and interpretations, and which can have very huge material impacts on the financial position and results in the company's financial statements [6].

May and Sunders [7] offers a frame work for organizing efforts directed at the process of accounting policy making and research related strategy. To them research into the selection of appropriate collective choice rule for accounting policy decision is one of the most difficult tasks. They concluded that no given research method will identify the most desirable accounting policy alternative. However, the use of many different research 
methods can provide data useful to accounting policy makers who must predict consequences of accounting alternatives and preference over those consequences. The different methods will serve as a building block in a complete accounting policy decision.

In a related but different issue concerning accounting policy decision, it is believed that accounting policy decision is dependent on resources available and as such, policy makers should go beyond comparing alternative policies regarding the degree to which their output conform to certain purely technical as well as aesthetic standards. Furthermore, accounting policy makers must employ a decision model that is sensitive to individual preference. He however concluded that the selection of a collective choice rule is impeded by the impossibility to construct collective choice rules that satisfy a minimal set of general conditions [8].

\subsection{Conceptual Basis of Accounting and Policy Disclosure}

According to Blooms and Elgers [9], the fourth major trend in corporate disclosures is the elusive concept of materiality which assumes two special significances:

1. Most users of accounting information do not comprehend it easily and consequently the introduction of redundant information can make the task of absorption of analysis more difficult. The presentation of significant date can also misleading,

2. The process of auditing arises at a satisfactory level of assurance regarding the fairness of presentation of financial statements at a point in time. Never is this assurance complete where it is economical or necessary to arrive at $100 \%$ assurance.

Blooms and Elgers [9] then concluded that the problems in relation to materiality concept is that which constitutes materiality lacks guidelines that requires the need for anterior in assessing item of paramount importance and uniformity in assessment. Furthermore the disclosure of accounting policies should identify and describe the accounting principles followed by reporting entity and the method of applying those principles that materially affects the determination of firms' position or result of operations.

\subsection{Accounting Policies and Disclosure Techniques}

As an initial step in improving transparency of companies' financial disclosures, American Securities and Exchange Commission has proposed disclosure requirements that enhance investors understanding of the application of companies' critical accounting policies. The comprehensive package of information of all kinds must completely describe an organization economic activity. Business entities of significant size have a public accountability to provide specified information. In the world of corporate report the idea is that there is an implicit responsibility to report publicly incumbent on every economic entity where size renders its significance. Corporate reports are meant to communicate economic measurement of the resources and performance of the reporting entity to those having reasonable right to such information. To achieve this, the corporate report must possess the characteristics of objectivity, relevance, reliability, consistency, comparability [10].

According to Hindsmark [11] financial reports are not required to follow any particular format or sequence. Current disclosures requirement must be criticized for their failure to require standardization of format. Delmer [12] pointed out that the principal objection to the balance sheet as it is currently presented is that it does not show the current value of many items listed in it. The author therefore proposed abandoning the balance sheet as a statement of financial reporting purpose. It would be replaced by separate statement such a statement of solvency, a statement of property, plant and machinery and statement of owner's equity. Richard and Richard [13] pointed out that the short comings of the traditional working capital treatment, when it is applied to the balance sheet of certain service industries.

\subsection{Uniformity and Comparability of Financial Statement}

Uniformity and comparability of financial statements have different goals. The goal of uniformity frequently implies the presentation of financial statement by different organizations using the same accounting procedures, measurement concepts, classifications, and methods of disclosure, as well as a similar basic format in the statement. The goal of comparability is to facilitate the making of predictions and financial decisions by creditors, investors, amongst others. Comparability may be defined as the quality or state of having enough like characteristics to make comparison appropriate [14].

Comparability of financial reports of organizations in similar line of activities, for example listed companies in Nigerian Stock Exchange will make for an influential financial report as regards decisions which investors make. Soyode [15] opines that, most decisions involve a comparison of the same organization overtime. In light of this, accounting is useful to the extent that it permits meaningful comparison. Barton [16] also corroborated Soyode's submission by stating that, accounting information is more useful if it facilitates comparisons as all decision making, control and evaluations involve comparison. Comparability, he continued, means that like things are measured and reported similarly and that these are distinguished from the unlike 
things. Comparability requires that a consistent set of accounting principles, definitions, assumptions, data processing and measurement, techniques, classifications of data and reporting intervals are applied [17].

It can be gathered, for a listed company to cope with its environmental opportunities and threats, it has to be able to carry out reasonable comparison of its financial position with that of other listed companies and if possible other organizations, before reasonable decisions can be made. Also similar accounting bases and principles for measurement and reporting among listed companies have to be in place [15] [16].

However, there is opposition to uniformity by financial statements of organizations within the same industry. This is because some researchers [18] appear to confuse the concept of comparability with basic identity. And they are of the opinion that comparability cannot be achieved because of the absence of basic identity. According to Kemp [19], the idea that financial statements of two organizations should be comparable is based on the assumption that the organization themselves are comparable, which might or might not be true. But Kemp fails to realize that comparability does not require the existence of identical operating conditions. The existence of differences in operating conditions does not require, however, that attention should be given to figuring out dissimilar circumstances. This agrees with the view of Simmon [20] who submits that, the objective of financial reporting is to reflect similarities as similarities and differences as differences. Hence, the fact that basic identity does not exist among organizations enhances the importance of achieving comparability in financial reporting in listed companies in Nigeria.

\subsection{Quality of Financial Statement}

According to Sengupta [21], quality of financial statements can be assessed based on measures of quality, which includes relevance, materiality, consistency and timeliness. The quality of financial statement is very important to the users. In this claim, it is submitted that a lack of quality in financial disclosure increases variations in the market price of the corporation's stock. It also suggests that timely disclosure of relevant information tends to prevent surprises, which may completely alter the outlook for the future of the firm. It also tends to give investors greater confidence in the financial information.

The US Financial Accounting Standard Board [22] submits that, the concept of relevance requires that information must bear upon or be usefully associated with actions it is designed to facilitate or result desired to be produced. In this research, by concept of relevance, we mean that of decision relevance; that is emphasis is placed on accounting information that can be useful in either normative or descriptive decision models. The concept of relevance implies that all information should be presented which may aid in the prediction of the types of information required in the decision processes, which may aid directly in the making of decisions. Street and Gray [23] opine that, the concepts of relevance and materiality tend to be very similar in many respects. The concept of materiality can be used in a positive sense to determine what should be disclosed for general undefined uses. That is, information may be considered to be material, and thus disclosed as necessary, if the knowledge of this information may be significant to the users of accounting reports. Materiality may be looked upon as a constraint determined by the inability of the specific users handling large masses of detail. One of the responsibilities of the accountant in financial reporting is to summarize this mass of data in such a way that it will be meaningful to the users of the reports. Too much data can be just as misleading as too little.

The doctrine of consistency has been a basic tenet in accounting for many years. It has been used to refer to the use of the same accounting procedures by a single accounting entity from period to period. The consistency constraint is valid only when there is a choice among two or more equally relevant and valid procedures [24]. For financial information to be timely, the accumulation and summarization of accounting information and its publication should be as rapid as possible to assure the availability of current information in the hands of the users. This also implies that, financial statements should be presented at frequent intervals, to reveal changes in the firm's situation, which may in turn affect the users' predictions and decisions.

\subsection{Presentation, Disclosure and Content of Financial Statements}

By presentation of financial statements, we mean the form, types of numbers presented and the layout or format and arrangement of items like assets and liabilities. Financial statements are prepared for the purpose of presentation a periodical review or report on progress by the management and to deal with the status of the investment in the business and the results achieved during the period under review [17].

According to Botosan and Harris [10], disclosure in financial statements means the presentation of information necessary for the optimum operation of an organization or capital markets. How much information should be disclosed is dependent not only on expertise of the reader also on the desirable standard. The three concepts of disclosure generally proposed are adequate, fair and full disclosure. By adequate disclosure we imply a minimum account of disclosure congruous with the negative objective of making the statement not misleading. Fair disclosure implies an ethical objective of proficiency equal treatment for all potential readers. Full disclosure implies the presentation of all relevant information. To some writers, full disclosure means the presentation of superfluous information and is therefore inappropriate. Too much information is not good in that the presentation of unimportant details hides the significant information and makes the financial reports difficult 
to interpret [25]. However, appropriate disclosure of information is significant to investors and others. Therefore, financial statements should be adequate, fair and full. According to Baiman and Verreechia [26], there are several different methods of making disclosures. The selection of the best method of disclosure in each case depends on the nature of the information and its relative importance. The common methods of disclosure are form and arrangements of formal statements, terminology and detailed presentations, parenthetical information, notes on the accounts, supplementary statements and schedules, comments in auditors' certificates and the letter of the board chairman.

Baiman and Verreecchia [26] views content of financial statements as the numbers published rather than how they are to be published. It encompasses disclosure content which specifies the items that must be included in the financial statements; and specific construct content which requires a theory from which operational rules can be derived and which can be retrenched to adjudicate between alternative procedures.

\section{Methodology}

In order to give empirical support to this paper concerning the comparability of financial statements in listed companies in Nigeria, a cross sectional survey of the financial statements in the critical areas of the quality presentation, disclosure and content was conducted. The population of the study is made up of all listed companies in Nigerian Stock Exchange ending as at $31^{\text {st }}$ December 2010. The year 2010 was used as the cutoff date because between January 2011 and July 2011 access to data of listed companies in Nigeria for this study was not possible. This is a major methodological weakness in this study. However, access to financial statement of 12 listed companies as at $31^{\text {st }}$ December, 2010 was possible, therefore these 12 listed companies made up the sample size, by using the judgmental sampling technique.

A general view of the nature of accounting practices and reports of these listed companies was also covered and extent of their uniformity and comparability ascertained. The inferential statistics (chi-square statistic U.M.P. invariant test) was employed in testing the tentative statements made in this study. The choice of this statistical tool is because the basic empirical operation in this study is determination of uniformity/equality.

The conceptual and all the textual information from the foregoing are summed up to assert that the content of financial statements make up the four main divisions of uniformity and therefore generate the first, second, third and fourth proposals that the quality of the financial statement of listed companies in Nigeria are not different from each other; there is uniformity in the presentation of the financial statement of listed companies in Nigeria; the disclosures and content of the financial statements of listed companies are the same; the overall accounting policies and practices in listed companies in Nigerian Stock Exchange are uniform.

\section{Data Analysis, Results and Discussion}

Data analysis focused on testing of the uniformity and comparability of the six groups. This is as discussed below under quality, presentation, disclosure and overall accounting practice.

\section{Proposition I: Quality of Financial Statement}

Ho: $\mathrm{P}_{1}=\mathrm{P}_{2}=\mathrm{P}_{\mathrm{k}}$

Ha: $\mathrm{P}_{1}+\mathrm{P}_{2}=\mathrm{P}_{\mathrm{k}}$

The expected and observed version of chi-square $\left(\mathrm{x}^{2}\right)$ given by the relation:

$$
\mathrm{x}^{2}=\sum_{\mathrm{p}=1}^{\mathrm{n}} \underset{[\mathrm{Fo}-\mathrm{Fe}) 2]}{[\mathrm{Fe})} \text { was adopted to test the first hypothesis. }
$$

From the $\mathrm{x}^{2}$ table 1 , at (12-1) 11 degree of freedom with 0.05 level of significance, tabulated $\mathrm{x}^{2}=19.68$. Since calculated $x^{2}(19.5)$ is lesser, we accept the null hypothesis that the quality of the financial statements of listed companies in Nigeria differs.

Table I

\begin{tabular}{|c|c|c|c|c|c|}
\hline Listed Companies & $\mathrm{F}_{\mathrm{o}}$ & $\mathrm{F}_{\mathrm{e}}$ & $\mathrm{F}_{\mathrm{o}}-\mathrm{F}_{\mathrm{e}}$ & $\left(\mathrm{F}_{\mathrm{o}}-\mathrm{F}_{\mathrm{e}}\right)^{2}$ & $\frac{(\mathrm{Fo}-\mathrm{Fe})^{2}}{\mathrm{~F}_{\mathrm{e}}}$ \\
\hline 1 & 2 & 4 & -2 & 4 & 1.00 \\
\hline 2 & 1 & 4 & -3 & 9 & 2.25 \\
\hline 3 & 1 & 4 & -3 & 9 & 2.25 \\
\hline 4 & 1 & 4 & -3 & 9 & 1.00 \\
\hline 5 & 2 & 4 & -2 & 4 & 1.00 \\
\hline 6 & 2 & 4 & -2 & 4 & 1.00 \\
\hline 7 & 2 & 4 & -2 & 4 & 2.25 \\
\hline 8 & 1 & 4 & -3 & 9 & 2.25 \\
\hline 1 & 1 & 4 & -3 & 9 & 2.25 \\
\hline 11 & 1 & 4 & -3 & 9 & 1.00 \\
\hline
\end{tabular}


Field Survey and annual reports of sampled listed companies

Proposition II: Presentation of Financial Statement

The U.M.P. invariant test, postulated by Lehmann [27] given by the relation

$\mathrm{X} 2=\mathrm{n} \sum^{\mathrm{m}} \quad \frac{(\mathrm{vp}-\mathrm{np})}{\mathrm{n}} \mathrm{:}$ is the sample size,

$\mathrm{Vp}$ : is $\mathrm{x}^{2} / \mathrm{n}$,

$\mathrm{x}^{2}$ is the number of trials resulting in the outcome,

$\mathrm{M}$ : is possible number of $\mathrm{p}^{\text {th }}$ outcome,

$\pi \mathrm{p}:$ is $1 / \mathrm{n}$

Table II

\begin{tabular}{|c|c|c|c|c|c|c|}
\hline $\begin{array}{c}\text { Listed } \\
\text { Companies }\end{array}$ & Frequency & $\mathrm{Vp}$ & $\Pi \mathrm{p}$ & $(\mathrm{Vp}-\pi \mathrm{p})$ & $(\mathrm{Vp}-\pi \mathrm{p})^{2}$ & $\frac{(\mathrm{Vp}-\pi \mathrm{p})^{2}}{\frac{\pi \mathrm{p}}{}}$ \\
\hline 1 & 3 & $3 / 12$ & $1 / 12$ & $1 / 6$ & 0.028 & 0.336 \\
\hline 2 & 3 & $3 / 12$ & $1 / 12$ & $1 / 6$ & 0.028 & 0.336 \\
\hline 3 & 0 & 0 & $1 / 12$ & $1 / 12$ & 0.007 & 0.084 \\
\hline 4 & 3 & $3 / 12$ & $1 / 12$ & $1 / 6$ & 0.028 & 0.336 \\
\hline 5 & 0 & 0 & $1 / 12$ & $1 / 12$ & 0.007 & 0.084 \\
\hline 6 & 0 & 0 & $1 / 12$ & $1 / 12$ & 0.007 & 0.084 \\
\hline 7 & 3 & $3 / 12$ & $1 / 12$ & $1 / 6$ & 0.028 & 0.336 \\
\hline 8 & 0 & 0 & $1 / 12$ & $1 / 12$ & 0.007 & 0.084 \\
\hline 9 & 0 & 0 & $1 / 12$ & $1 / 12$ & 0.007 & 0.084 \\
\hline 10 & 0 & 0 & $1 / 12$ & $1 / 12$ & 0.007 & 0.084 \\
\hline 11 & 0 & 0 & $1 / 12$ & $1 / 12$ & 0.007 & 0.084 \\
\hline 12 & 0 & 0 & $1 / 12$ & $1 / 12$ & 0.007 & 0.084 \\
\hline \multicolumn{7}{|c|}{ Calculated $\mathrm{x}^{2}=2.016 \times 12=24.192$} \\
\end{tabular}

Source: Field survey and annual reports of sampled listed companies

From the $\mathrm{x}^{2}$ table 2, at eleven (11) degree of freedom with 0.05 level of significance, tabulated " $\mathrm{x}$ " " $=19.68$. Reject null hypothesis because calculated $x^{2}$ is greater than tabulated $x^{2}$. Therefore, there is uniformity in the presentation of the financial statement of listed companies in Nigeria.

Proposition III Disclosures in Financial Statements

Table III:

\begin{tabular}{|c|c|c|c|c|c|c|}
\hline $\begin{array}{c}\text { Listed } \\
\text { Companies }\end{array}$ & Frequency & $\mathrm{Vp}$ & $\pi p$ & $(\mathrm{Vp}-\pi \mathrm{p})$ & $(\mathrm{Vp}-\pi \mathrm{p})^{2}$ & $\frac{(\mathrm{Vp}-\pi \mathrm{p})^{2}}{\underline{\pi p}}$ \\
\hline 1 & 0 & 0 & $1 / 12$ & $-1 / 12$ & 0.007 & 0.084 \\
\hline 2 & 0 & 0 & $1 / 12$ & $-1 / 12$ & 0.007 & 0.084 \\
\hline 3 & 1 & $-1 / 12$ & $1 / 12$ & 0 & 0.000 & 0.000 \\
\hline 4 & 0 & 0 & $1 / 12$ & $1 / 12$ & 0.007 & 0.084 \\
\hline 5 & 0 & 0 & $1 / 12$ & $1 / 12$ & 0.007 & 0.084 \\
\hline 6 & 0 & 0 & $1 / 12$ & $1 / 12$ & 0.007 & 0.084 \\
\hline 7 & 1 & $1 / 12$ & $1 / 12$ & 0 & 0.000 & 0.000 \\
\hline 8 & 1 & $1 / 12$ & $1 / 12$ & 0 & 0.000 & 0.000 \\
\hline 9 & 3 & $1 / 4$ & $1 / 12$ & $1 / 6$ & 0.028 & 0.036 \\
\hline 10 & 0 & 0 & $1 / 12$ & $1 / 12$ & 0.007 & 0.084 \\
\hline 11 & 3 & $1 / 4$ & $1 / 12$ & $1 / 6$ & 0.028 & 0.336 \\
\hline 12 & 1 & $1 / 4$ & $1 / 12$ & 0 & 0.000 & 0.000 \\
\hline \multicolumn{7}{|c|}{ Calculated $\mathrm{x}^{2}=1.176 \times 12=14.112$} \\
\hline
\end{tabular}

Source: Field survey and annual reports of sampled listed companies

Proposition IV: Content of Financial Statement

\begin{tabular}{|c|c|c|c|c|c|c|}
\hline $\begin{array}{c}\text { Listed } \\
\text { Companies }\end{array}$ & Frequency & $\mathrm{Vp}$ & $\Pi p$ & $(\mathrm{Vp}-\pi \mathrm{p})$ & $(\mathrm{Vp}-\pi \mathrm{p})^{2}$ & $\frac{(V p-\pi p)^{2}}{\underline{\pi p}}$ \\
\hline 1 & 0 & 0 & $1 / 12$ & $-1 / 12$ & 0.007 & 0.084 \\
\hline 2 & 0 & 0 & $1 / 12$ & $-1 / 12$ & 0.007 & 0.084 \\
\hline 3 & 0 & 0 & $1 / 12$ & $-1 / 12$ & 0.000 & 0.000 \\
\hline 4 & 0 & 0 & $1 / 12$ & $-1 / 12$ & 0.007 & 0.084 \\
\hline 5 & 2 & $1 / 6$ & $1 / 12$ & $-1 / 12$ & 0.007 & 0.084 \\
\hline 6 & 3 & $1 / 4$ & $1 / 12$ & $1 / 6$ & 0.028 & 0.336 \\
\hline 7 & 3 & $1 / 4$ & $1 / 12$ & 0 & 0.028 & 0.336 \\
\hline 8 & 1 & $1 / 12$ & $1 / 12$ & 0 & 0 & 0 \\
\hline 9 & 1 & $1 / 12$ & $1 / 12$ & 0 & 0 & 0 \\
\hline 10 & 1 & $1 / 12$ & $1 / 12$ & 0 & 0 & 0 \\
\hline 11 & 1 & $1 / 12$ & $1 / 12$ & 0 & 0 & 0 \\
\hline 12 & 0 & 0 & $1 / 12$ & $-1 / 12$ & 0.007 & 0.084 \\
\hline
\end{tabular}


Table IV:

Source: Field survey and annual reports of sampled listed companies

From the $\mathrm{x}^{2}$ table 3 and 4 , at eleven (11) degree of freedom with 0.05 level of significance, tabulated $\mathrm{x} 2$ $=19.68$. Accept null hypothesis because calculated " $x^{2 "}$ " is less than tabulated " $x^{2 "}$. Therefore, the disclosures and content of the financial statement of listed are not uniform.

From the $\mathrm{x}^{2}$ table V, at eleven (11) degree of freedom with 0.05 level of significance, tabulated " $\mathrm{x}$ " $=$ 19.68. Accept null hypothesis because calculated " $x^{2 "}$ " is less than the tabulated " $x^{2}$ ". Therefore, the overall accounting policies and practices in listed companies are not uniform.

Proposition V: Overall Accounting Policies

Table V:

\begin{tabular}{|c|c|c|c|c|c|c|}
\hline $\begin{array}{c}\text { Listed } \\
\text { Companies }\end{array}$ & Frequency & $\mathrm{Vp}$ & $\Pi \mathrm{p}$ & $(\mathrm{Vp}-\pi \mathrm{p})$ & $(\mathrm{Vp}-\pi \mathrm{p})^{2}$ & $\frac{(\mathrm{Vp}-\pi \mathrm{p})^{2}}{\Pi p}$ \\
\hline 1 & 1 & $1 / 12$ & $1 / 12$ & 0 & 0 & 0 \\
\hline 2 & 1 & $1 / 12$ & $1 / 12$ & 0 & 0 & 0 \\
\hline 3 & 1 & $1 / 12$ & $1 / 12$ & 0 & 0 & 0 \\
\hline 4 & 1 & $1 / 12$ & $1 / 12$ & 0 & 0 & 0 \\
\hline 5 & 1 & $1 / 12$ & $1 / 12$ & 0 & 0 & 0 \\
\hline 6 & 1 & $1 / 12$ & $1 / 12$ & 0 & 0 & 0 \\
\hline 7 & 1 & $1 / 12$ & $1 / 12$ & 0 & 0 & 0 \\
\hline 8 & 1 & $1 / 12$ & $1 / 12$ & 0 & 0 & 0 \\
\hline 9 & 1 & $1 / 12$ & $1 / 12$ & 0 & 0 & 0 \\
\hline 10 & 1 & $1 / 12$ & $1 / 12$ & 0 & 0 & 0 \\
\hline 11 & 1 & $1 / 12$ & $1 / 12$ & 0 & 0 & 0 \\
\hline 12 & 1 & $1 / 12$ & $1 / 12$ & 0 & 0 & 0 \\
\hline
\end{tabular}

Source: Field survey and annual reports of sampled listed companies

The result of this work suggests that listed companies in Nigerian Stock Exchange are uniform in the form, types of numbers presented and the layout or format and arrangement of items like assets and accounting policies. However it is sad to discover that listed companies in Nigerian Stock Exchange are not uniform in terms of Relevance, materiality, consistency and timeliness of their financial statements; and Disclosure of information necessary for the optimum operation of an organization.

This makes it difficult for listed companies in Nigerian to make influential financial reports and also not to be able to cope effectively with environmental threats and opportunities, in the sense that they fail to recognize and evaluate accounting policies and practices being adopted by listed companies in Nigeria for informed decisions.

\section{Conclusions}

This paper covers twelve listed companies in Nigeria. Also involved were the financial controllers/unit accountants of these companies. The study also covered a general view of the nature of accounting practices and reports of the listed companies and reports of these listed companies and ascertained their extent of uniformity and comparability.

In order to give empirical support to this paper concerning the uniformity and comparability of financial statements in listed companies, a survey of the financial statements in the critical area of the quality, presentation, disclosure and content was conducted, and the result of this work suggests that listed companies in Nigeria are uniform in the form, types of numbers presented and the layout or format and management of items like assets and accounting policies. However, it was discovered that their accounting practices are not uniform in areas of quality, disclosure and content of their financial statements and therefore, their overall accounting practices. To make its financial report a vehicle of satisfactory communication and of value not only to those who take financial decisions for listed companies in Nigeria but to members of the Nigeria investors who have majority stake in these listed companies, the question of non uniformity in their accounting policies practice and report should be minimized it not eradicated.

\section{Recommendations}

The following suggestions are recommended to bring unified accounting policies application, practice and uniformity in accounting reports of quoted companies in Nigeria.

(1) The accounting policies laid down by the Securities and Exchange Commission (SEC) should be made to serve as a financial regulator as well as a standard for unified accounting practice and uniformity in financial statements of listed companies in Nigeria. 
(2) The Financial Reporting Council of Nigeria (FRCN) should be more active. The body should establish accounting practices which recognizes the status of listed companies and their activities and which should be adopted by all Nigerian listed companies to reduce or eliminate the areas of differences in their accounting practices and reports. This body should include representative of the Federal Government, Central Bank of Nigeria, Securities and Exchange Commission, Institute of Chartered Accountants of Nigeria (ICAN), Financial Reporting Council of Nigeria (FRCN) and other interest groups.

(3) The Nigerian listed companies should adopt the modified accrual accounting basis in their accounting system and use the same in revenue and expenditure recognition. Pure cash accounting basis should not be seen as acceptable or adequate and price accrual will encounter problems in application because, some items of revenue and expenditure in listed companies in Nigeria are susceptible to accrual basis.

(4) The current practice of subjecting the financial statements to audit by external auditors is good and should be continued. It is believed that if these recommendations are noted, the quality of accounting in listed companies in Nigeria will not only be improved but the question of non uniformity in their accounting practice and report will be minimized if not eradicated.

\section{References}

[1] O. Obasanjo, Audited Accounts now condition for funds release: The Guardian Newspaper, October 4, (2000).

[2] I.M. Pandey, Financial management, $\left(10^{\text {th }}\right.$ ed); Delhi: Vikas publishing, (2010).

[3] T. Beck and R. Levine, Legal institutions and financial development, in handbook of new institutional economics, Claude Netherlands, Springer, (2005)

[4] G. Caprio and D. Klingebiel, Episodes of systematic and boarder line financial distress, World Bank, (1999)

[5] R. K. Herdsman, Financial Accounting Standard Board and Economic Development, Bennad M. Barnoh College Press, USA, (1974)

[6] B. Desai, Empirical analysis of the quality of corporate financial disclosures, Accounting Review 22 (January), (1996)

[7] May and Sunders, Accounting policies formulation and application, Branph College Press, USA, 214 (1976)

[8] J.S. Demski, The value of financial accounting, Accounting Journal Standard, University Graduate School of Business, Stanford, USA, (1994).

[9] Bloom and Elgers, Accounting theory and policy, Harcourt Brace Incorporated, USA, (1981)

[10] C. Botosan, and M. Harris, Motivations for a change in disclosure frequency and its consequences: an examination of voluntary quarterly segment disclosures, Journal of Accounting Research, 38, (2000), 329 - 353

[11] J. Hindsmark, The English Illustrated Dictionary, Oxford University Press, London, (1983).

[12] P. I. Delmer, Should we dismantle the balance sheet? Finance Executive, (1977), USA

[13] G. Richard, and N. Richard, Objective of accounting in dynamic society, The Nigerian Accounting; XIII (3), (1988).

[14] G. Meek and S. Sandagaran, A survey of research on financial reporting in a transnational context, Journal of Accounting literature, 9, (1990), $52-74$

[15] A. Soyode, Financial accounting: principles and practice ( $1^{\text {st }}$ Edition), Graham Burn, Bedfordshire, (2010).

[16] A. D. Barton, The anatomy of accounting, University of Queen Land Press, U.K. ( $2^{\text {nd }}$ Edition), (2000).

[17] J. Cole, A review of the empirical disclosure literature: a discussion, Journal of Accounting and Economics 31, (2001), 441 - 456

[18] D. Acemoglu, S. Johnson, and J. A. Robinson, The colonial origins of comparative analysis: an empirical investigation, American Economic review 91, (2001), 1369 - 1401

[19] P. S. Kemp, Controversies in the construction of financial statements, Accounting Review, 16 (January), (2005)

[20] J. K. Simmon, A concept of comparability in Financial Reporting, Accounting Review, 12, (October), (1999)

[21] P. Sengupta, Corporate Disclosure Quality and the cost of debt, The Accounting Review 73, (1998), 459 - 479.

[22] FASB, Statement of financial accounting reporting by business enterprises, Financial Accounting Standards Board, NY, (1978)

[23] D. Street and S. Gray, Observance of International Accounting Standards: factors explaining non - compliance, ACCA Research Report (74) (2001)

[24] R.W. Leftwich,, R. L. watts and J. L .Zimmerman, Voluntary corporate disclosure: the case of interim reporting, Journal of Accounting Research 18 (1981), 50 - 11

[25] A. Admati, and P. Pfleiderer, Forcing firms to talk: financial disclosure regulation and externalities; Review of financial studies 13, (2000) $479-519$.

[26] S. Baiman and R.E. Verrecchia, The relation among capital markets, financial disclosure, production efficiency, and insider trading, Journal of Accounting Research 34, (1996), 1 - 22

[27] S. Lehmann, Statistics Today, Illinois: Johnson Wise, (1962).

${ }^{1}$ Augustine O. Okolie earned his Doctor of Philosophy (Ph. D) in Accounting from the University of Benin, Benin City, Nigeria. Dr. Augustine Okolie is a Senior Lecturer in Accounting at Ambrose Alli University, Ekpoma, Nigeria. He is a fellow of the Institute of Chartered Accountants of Nigeria (FCA).

${ }^{2}$ Nosa, A. E. Omoregie obtained his M Sc degree in Accounting from the University of Benin, Benin City, Nigeria. Omoregie, A. E. Nosa is a lecturer in Accounting and Faculty member, Faculty of Management Sciences, Ambrose Alli University, Ekpoma, Nigeria 